\title{
Toxic Air Pollutants Notice of Construction, Rotary Mode Core-Sampling Truck and Exhauster
}

Date Published

May 1993

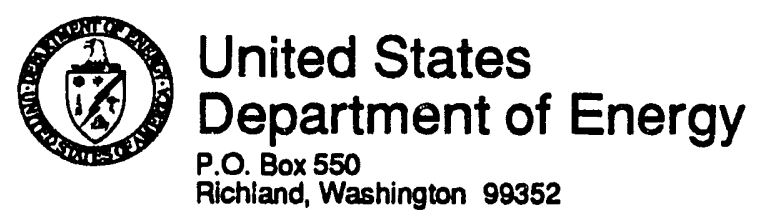

Approved for Public Release 
1.0 INTRODUCTION . . . . . . . . . . . . . . . . . . 1

2.0 PROCESS INFORMATION ..................... 1

3.0 CONTROL EQUIPMENT INFORMATION . . . . . . . . . . . . . 2

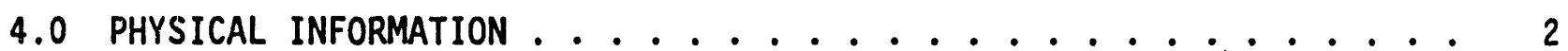

5.0 PROCESS FLOW INFORMATION .................... 3

5.1 EXHAUSTER DESIGN ....................... 3

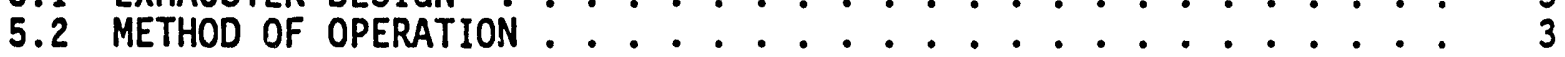

6.0 EMISSIONS ESTIMATION .......................... 5

7.0 COMPLIANCE WITH REQUIREMENTS ................... 8

8.0 REFERENCES . . . . . . . . . . . . . . . . . . 9

APPENDIXES:

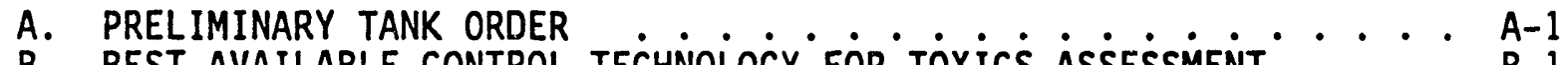

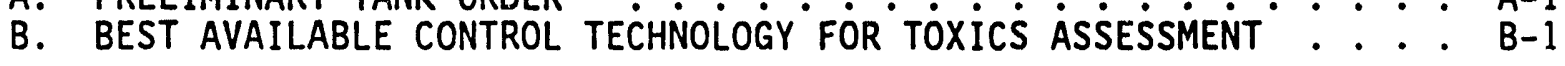

\section{LIST OF FIGURES}

1. Design Drawing of Exhaust System ................ . 4

\section{LIST OF TABLES}

1. Vapor Space Concentration .................. 6

2. Emissions Estimate ................... 8 
DOE/RL 93-41

\section{ACRONYMS}

ASIL acceptable source impact level

HEPA

SST

high-efficiency particulate air

single-shell tank

T-BACT

TAP

best available control technology for toxics

TOC

Tri-Party

Toxic Air Pollutant

Agreement

VOC

Total Organic Compounds

WAC

Hanford Federal Facility Agreement and Consent Order volatile organic chemicals

Washington Administrative Code 
STATE OF WASHINGTON DEPARTMENT OF ECOLOGY

NOTICE OF CONSTRUCTION APPLICATION

DECLARING INTENT TO CONSTRUCT, INSTALL, OR ESTABLISH

A NEW AIR CONTAINMENT SOURCE

OR

REPLACEMENT OR SUBSTANTIAL ALTERATION OF

EMISSION CONTROL TECHNOLOGY ON AN EXISTING STATIONARY SOURCE

\section{GENERAL INFORMATION}

1. Business Name U.S. Department of Energy. Richland Operations Office

2. Business Address P.O. Box 550, Richland, WA 99352

3. Business Phone Number (509) 376-8566

4. Location of Source 200 Areas, Hanford Site

5. Nature of Business Sampling of radioactive mixed wastes stored in underground tanks

6. Construction Starting Date September 15, 1993

7. Construction Completion Date September 30, 1993

8. Describe Input to Output Process (Attach drawings, schematics, prints or block diagrams) See attached document.

9. General Location (check) Rural $X$ Urban

10. Process

Production Output Per Year (tons pounds) N/A

Maximum Output Per Hour (tons pounds) $N / A$

Percentage of Production (\%) Dec-Feb

Mar-May

Jun-Aug

Sep-Nov

Operating Schedule

Hrs/Day

Day/Wk

Wk/Year up to 24

up to 7

up to 52 
II. Emissions Estimations and Calculations

1. Criteria Pollutants (gr/dscf, tons/yr, $1 \mathrm{bs} / \mathrm{hr}, \mathrm{ppm}$, etc.)

Particulates 0.000017 tons/yr

Volatile Organic Compounds 0.0378 tons/yr

Sulfur Oxides

Nitrogen Oxides

Carbon Monoxide

Lead

2. Tuxic Pollutants (Name) (gr/dscf, tons/yr, lbs/hr, ppm, etc)

See attached document.

3. Fugitive Pollutants (Source) (gr/dscf, tons/yr, pounds/etc) None Expected

4. Air Pollution Modelling

Results None required

Computer Printout Attached 
III. Emissions Data

1. Stack Height (feet) over 10 feet

Inside Diameter (feet) 0.33 feet ( 1 inches)

Gas Exit Temp (degrees F) Variable

Gas Exit Velocity $(\mathrm{ft} / \mathrm{min}) 2300 \pm 600 \mathrm{ft} / \mathrm{min}$

Flow Rate (cfm) $200 \pm 50 \mathrm{cfm}$

Shared Stack? No

Distance From Stack to Property Line At least $16 \mathrm{~km}$

2. Discharge Point or Points (if no stack or other than stack)

Height (feet)

Inside Diameter or Dimensions (feet)

Gas Exit Temp (degrees F)

Gas Exit Velocity ( $\mathrm{ft} / \mathrm{min}$ )

Gas Flow Rate (cfm)

Shared Discharge

Distance From Stack to Property Line

3. Fue? Type $N / A$

$\%$ Sulfur

$\%$ Ash

Unit of Measure (gal, cuft, etc)

BTU per Unit of Measure

Consumption Units per Year

Maximum Consumption Units per Hour

4. Building Dimensions

Height (feet) N/A

Length (feet) $N / A$

Width (feet) N/A 
IV. Air Pollution Control Equipment (Refer to BACT Instructions)

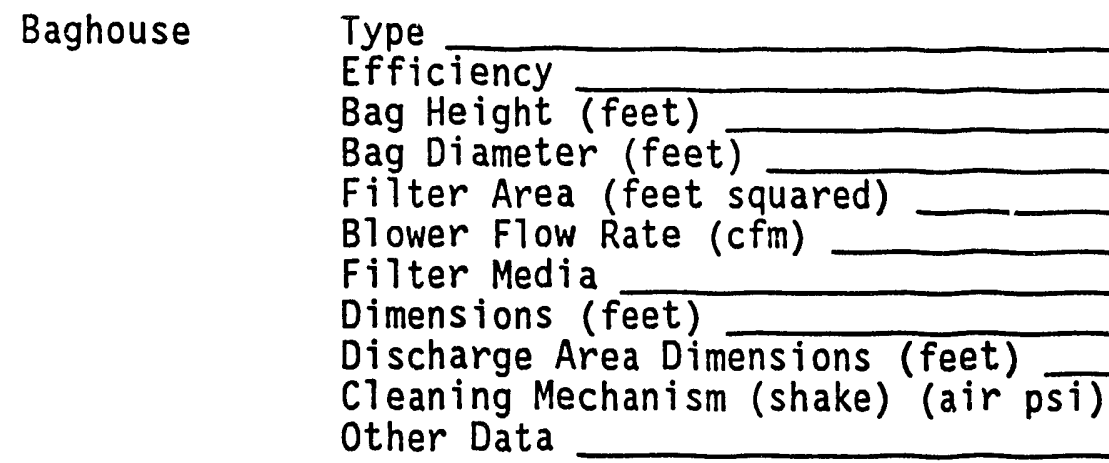

Scrubber Type

Efficiency

Gas Differential Pressure (psi)

Liquor Differential Pressure (psi)

Liquor Flow (gpm)

Discharge Area Dimensions (feet)

Gas Flow (cfm)

Other Data

Cyclone Type

Efficiency

Gas Flow (cfm)

Discharge Area Dimensions (feet)

Other Data

Precipitator Type

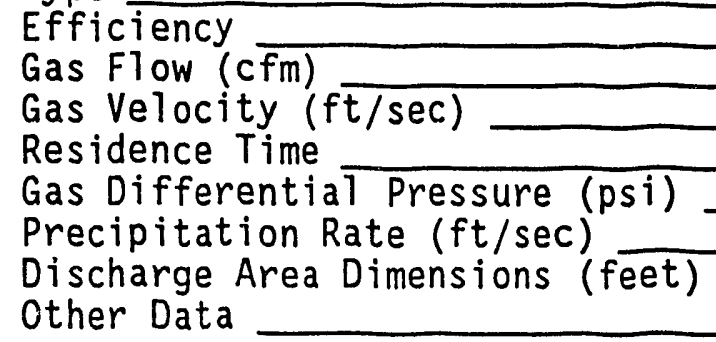

Ad/absorb Type

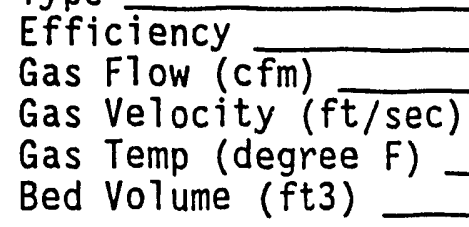

Bed Dimensions (feet)

Capacity (hours)

Contaminant (1b/day)

Regeneration Time (hours) 
Other

Type Fabric HEPA Filter

Efficiency $99.95 \%$ at $0.3 \mu \mathrm{m}$ and larger

Gas Flow (cfm) $200 \pm 50 \mathrm{cfm}$

Discharge Area Dimensions (feet) N/A

V. Additional Information

1. Fugitive Dust Control Plan (Attach if Necessary)

No additional fugitive dust controls are planned in addition to current operations.

2. Attach Operation and Maintenance Manual of Pollution Control Equipment. Yes No $X$

3. Attach Vendor Information or Manufacturer's Instructions on Pollution Control Equipment. Yes No $X$

4. Attach Related information on Chemicals or Materials that will be Emitted (MSDS Sheets, Company Information, etc.) Yes No $X$

5. Name and Title of Individual Filling out Form

(print) J.D. Bauer, Program Manager, Office of Environmental Assurance, Permits, and Policy

(sign)

6. Date

7. Name and Title of Contact Person if Different from Above S. D. Stites, Physical Scientist 
DOE/RL 93-41

This page intenijonally left blank. 


\section{TOXIC AIR POLLUTANTS NOTICE OF CONSTRUCTION ROTARY MODE CORE-SAMPLING TRUCK AND EXHAUSTER}

\subsection{INTRODUCTION}

Characterization of wastes in the single-shell tanks (SST) and doubleshell tanks on the Hanford Site is crucial in developing the final disposal option for the waste and closure strategy for the Site. Additionally, characterization of tank waste is important for the waste tank safety programs. The Hanford Federal Facility Agreement and Consent Order (Tri-Party Agreement) (Ecology et al. 1990) Milestone M-10-00 requires obtaining and analyzing at least two samples from each SST, and Milestone M-10-13 specifically requires the ability to sample hard saltcake. Existing equipment, however, does not allow sampling of all SSTs within established tank safety limits.

Consequently, the U.S. Department of Energy, Richland Operations Office has developed a rotary mode core-sampling system that uses nitrogen gas to cool and clear the drill bit. A rotary mode core-sampling truck will be used on approximately 80 SSTs that contain saltcake waste, and will provide crucial information on the contents of the tanks. This application is a request for approval to construct and operate the core-sampling truck and exhauster in the 200 East and 200 West Area Tank Farms of the Hanford Site. This request is being made pursuant to Washington Administrative Code (WAC) Chapter 173-460, "Controls for New Sources of Toxic Air Pollutants."

\subsection{PROCESS INFORMATION}

A new rotary mode core-sampling system has been designed to sample tanks containing hardened wastes. The prominent feature of this new system is the use of a nitrogen gas purge. The nitrogen gas purge will cool the drill bit and prevent cross contamination of different waste layers in the tank. The nitrogen gas purge will also allow more complete sample recovery by clearing cuttings that might otherwise obstruct the sampler or drill bit. Nitrogen was chosen over other compressed gases for its inherent safety.

Many of the tanks to be sampled with the rotary mode core-sampling system are not actively ventilated; they are operated at atmospheric pressure with passive (i.e., breather) high-efficiency particulate air (HEPA) filters. Unless a ventilation system of the proper capacity is used, addition of the nitrogen purge gas to SSTs will cause the tanks to pressurize. Additionally, the use of the rotary mode core-sampling system will generate aerosols and dusts in the tank vapor space. 
Consequently, an exhauster will be required during operation of the rotary mode core-sampling system on SSTs to prevent tank pressurization and to control emissions. This exhauster will be required to be moved from tank farm to tank farm with the rotary mode core-sampling system and may emit pollutants subject to WAC $173-460$.

The State of Washington Department of Ecology (Ecology), under the authority of the Tri-Party Agreement has been involved in the development of the rotary mode core-sampling truck. Tri-Party Agreement Milestone M-10-13 requires a demonstration of the ability to sample hard saltcake by September 1993. The exhauster described in this application is essential to meeting the milestone.

\subsection{CONTROL EQUIPMENT INFORMATION}

Particulate emissions will be controlled with prefilters and HEPA filters, which are being installed primarily to control radionuclide pollutants. The HEPA filters are rated to remove 99.95 percent of the particles that are $0.3 \mu \mathrm{m}$ and larger. Therefore, particulate emissions will not be of concern from this activity.

A discussion of the best available control technology for toxics (T-BACT) is included as Appendix B of this document. The recommendation of the T-BACT assessment is that no controls for volatile organic compounds (VOC) or volatile inorganic compounds be installed.

\subsection{PHYSICAL INFORMATION}

The rotary mode core-sampling system will be located in the 200 East and 200 West Areas of the Hanford Site. The stack will be over $3 \mathrm{~m}$ (10 ft) high, and have a $10-\mathrm{cm}$ (4-in.)-diameter duct. The average stack temperatures will be approximately $60^{\circ} \mathrm{C}\left(140^{\circ} \mathrm{F}\right)$ and the exhaust rate will be approximately $5.7 \pm 1.4 \mathrm{~m}^{3} / \mathrm{min}\left(200 \pm 50 \mathrm{ft}^{3} / \mathrm{min}\right)$. Vapor composition information is included in Section 5.0 . 


\subsection{PROCESS FLOW INFORMATION}

\subsection{EXHAUSTER DESIGN}

The conceptual design of the exhauster system (i.e., control equipment, fan, and stack) is shown in Figure 1. The first part of the exhauster system consists of an in-riser prefilter, which can be backwashed into the tank, to remove most of the larger particles and aerosols generated as a result of the rotary mode core-sampling. The second part consists of two testable HEPA filters, preceded by a prefilter. This second part is designed to remove the smaller particles, including particulate radionuclides. The fan and 3-m $(10-\mathrm{ft})$ stack complete the exhauster system. The stack will contain monitors for both total organic compounds (TOC) and ammonia.

\subsection{METHOD OF OPERATION}

Approximately 15 tanks could be sampled each year. Each tank will take approximately 1 month to sample. This includes set-up and break-down time, in addition to the time required to move the rotary mode core-sample truck one time at each tank (i.e., to allow two complete cores to be taken). The exhaust system will be operated only while sampling activities are underway (one or two 8-hour shifts of active sampling each day).

After the exhaust system and rotary mode core-sample system are connected to the tank to be sampled and all required preoperational tests are complete rotary mode core-sampling will progress. Included in the preoperational tests will be an analysis of the tank vapor composition. If concentrations of components listed in Section 6.0 exceed the maximum concentration provided in this NOC, the tank willi not be rotary mode core-sampled. Additionally, saipling may be deferred if independent safety organizations determine the concentration in the tank would jeopardize worker safety. If any tank exceeds the maximum value provided, a revision to this NOC, including, as necessary, a redesign of the exhauster with controls for the contaminant(s) of concern, will be provided.

An attempt will first be made to sample the waste using push mode. When instrumentation indicates that hard waste has been reached, the exhauster will be started and the drill bit will start rotating. Whenever the drill bit is rotating, nitrogen gas will be injected into the drill string at approximately $1.4 \mathrm{~m}^{3} / \mathrm{min}\left(50 \mathrm{ft}^{3} / \mathrm{min}\right.$ ) (to a maximum of $2.8 \mathrm{~m}^{3} / \mathrm{min}\left[100 \mathrm{ft}^{3} / \mathrm{min}\right]$ ). Each $48.3-\mathrm{cm}$ (19-in.) segment requires drilling for 5 to 20 min. "While the sampler is being changed out after each segment, nitrogen will be injected into the drill string at approximately $1 \mathrm{ft}^{3} / \mathrm{min}$. This will maintain the hydrostatic head in the drill string (preventing waste from entering the space just sampled), and allows for prissurization and de-pressurization of the sample receiver, as necessary for sampler change-out. 
DOE/RL 93-41

Figure 1. Design Drawing of Exhaust System.

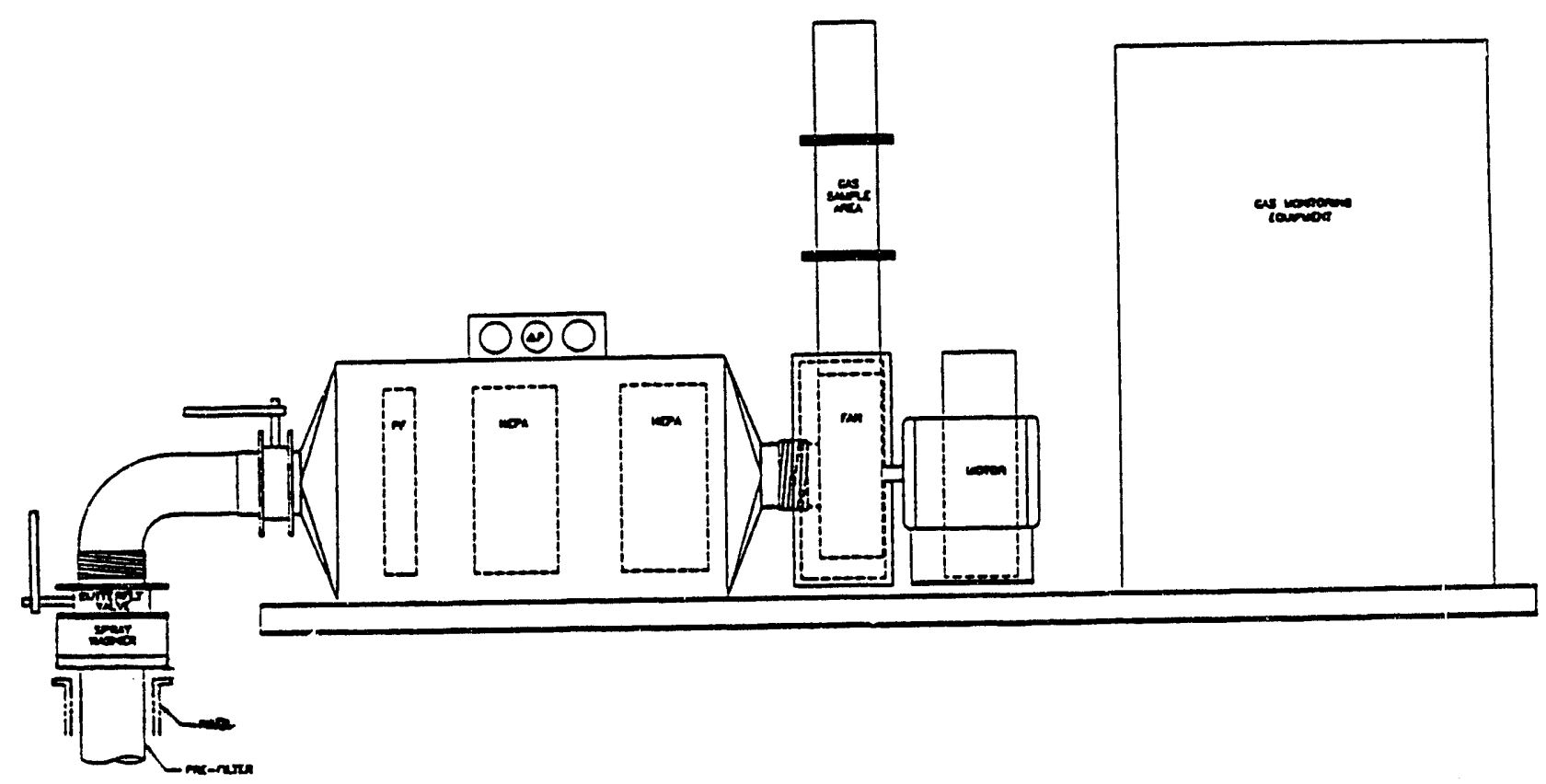


Once a complete core has been obtained, the position of the rotary mode core-sampling truck will then be changed to allow a secord core to be obtained. Upon completion of the second core, the exhauster and rotary mode core-sampling systems will be disconnected and moved to the next tank to be sampled.

When possible, movement of the exhauster and rotary mode core-sampling systems between tank farms will be limited. Several issues contribute to determining the order of tank sampling, and this will not always be possible. The first thirty tanks to be sampled using the rotary mode core-sampling system have been identified. Appendix A contains a preliminary list, which is subject to change with changing priorities.

The TOC monitor will record the total amount of organic compounds emitted to the atmosphere. A calculation of emissions of each compound can be determined, based on the TOC value and the preoperational vapor sampling, assuming the same ratio of components. This can be used to assure that annual smal1 quantity emission rates are not exceeded.

\subsection{EMISSIONS ESTIMATION}

The exact contents of the SSTs is not known, which is why the rotary mode core-sampling system was designed to provide more information on tank contents. Unfortunately, that makes determining the source term of the tanks for the purposes of this application difficult. Several approaches were taken to bound the projected emissions from the rotary mode core-sampling activities. Those approaches involved the use of process knowledge, computer modeling, tests on simulants, and limited laboratory analys is results. Some of the waste chemicals originally introduced to the SSTs are not necessarily present in the same composition, and species that were not introduced may have been generated in the tanks over time. This is a result of the conditions of the tank waste (i.e., temperature and $\mathrm{pH}$ ), the length of time the tanks have been inactive (no waste has been placed in SSTs since 1980), and reactions of chemicals within the tanks (including radiolysis).

A design basis vapor composition was developed for the primary contaminates expected in the tank (WHC 1993). This design basis represents a good engineering estimate of the vapor spaces to be exhausted with the proposed system. Additionally, a maximum anticipated concentration was also developed. Table 1, Vapor Space Contents, shows the design bas is concentration and the maximum anticipated concentration of each design basis contaminant subject to regulation by WAC 173-460.

Most SSTs have not had active ventilation on the vapor space for at least 10 years; all SSTs were declared inactive by 1980 . During that time, the volatile components of the waste have been allowed to come into equilibrium with the vapor space. Although exhausting the tanks may encourage the volatization of some chemicals from the tank waste, it is anticipated that during the relatively brief time of exhausting each tank, very little, if any, contaminants will volatilize from the waste. Using this assumption, the 
current vapor space is the only source term. The size of the vapor space can be calculated based on the depth of waste, the capacity of the tank, and the diameter of the tank. Unfortunately, the vapor space of the tank being sampled is not the only vapor space potentially exposed to the exhauster.

Table 1. Vapor Space Concentration.

\begin{tabular}{|l|c|c||c|}
\hline \multicolumn{1}{|c|}{ Contaminant } & $\begin{array}{c}\text { Design basis } \\
\text { concentration }\end{array}$ & $\begin{array}{c}\text { Maximum } \\
\text { concentration }\end{array}$ & $\begin{array}{c}\text { TAP } \\
\text { class }\end{array}$ \\
\cline { 2 - 4 } & $\mathrm{p} / \mathrm{M}$ & $\mathrm{p} / \mathrm{M}$ & $\mathrm{B}$ \\
\hline \hline Acetone & 50 & 160 & $\mathrm{~B}$ \\
\hline Butano1 & 100 & 400 & $\mathrm{~A}$ \\
\hline Benzene & 2 & 10 & $\mathrm{~B}$ \\
\hline (Hexane)/Octane $^{\mathrm{a}}$ & 2 & 10 & $\mathrm{~B}$ \\
\hline Methyl Amine & 10 & 80 & $\mathrm{~A}$ \\
\hline Carbon Tetrachloride & 1 & 5 & $\mathrm{~B}$ \\
\hline Ammonia & 200 & 700 & $\mathrm{~B}$ \\
\hline Hydrogen Cyanide & 1 & 110 & $\mathrm{~B}$ \\
\hline $\begin{array}{l}\text { Nitric } \\
\text { Acid/(0xides) }\end{array}$ & 10 & 50 & $\mathrm{~B}$ \\
\hline Carbon Disulfide & 1 & 5 & $\mathrm{~B}$ \\
\hline Hydrogen Sulfide & 1 & 5 & \\
\hline
\end{tabular}

a - The two pollutants were grouped together in determining the concentration. It is assumed that all of the group could be attributed to the pollutant with the lower ASIL. The pollutant with the higher ASIL is in parenthesis.

b - The compounds have very low probability of existence in the tank environment, and the current sampling system is not capable of detecting these compounds. Other methods available would increase wcrker exposure to radiation. The pre-operational sampling will not sample for these compounds, due to the high costs relative to the low probability of existence.

ASIL = acceptable source impact level $p / M=$ parts per million (PPM) TAP = toxic air pollutant.

Many SSTs are connected to one or two other tanks by underground overflow lines that were used when waste was cascaded from tank to tank in an effort to separate the solids (and much of the radioactivity) from the supernate. Those overflow lines now connect the vapor spaces of the tanks in a cascade. It is 
not known what percentage of these overflow lines are blocked, or the extent of blockage in each line, but the tanks cannot be isolated from other tanks in the cascade with any certainty. Consequently, when calculating the vapor space available for the exhauster, the vapor space of the other tanks in the cascade must be accounted for.

The calculation of total available vapor space was performed on the tanks to be rotary mode core-sampled (15 tanks per year, a very aggressive schedule) in the first $2 \mathrm{yr}$ and it was determined that approximately $193,000 \mathrm{~m}^{3}$ ( 6.8 million $\mathrm{ft}^{3}$ ) of vapor space is available to the exhauster. This includes the vapor space of the tanks connected to the tanks being sampled.

( 2.3 million $\mathrm{ft}^{3}$ for the tanks being sampled, plus 4.5 million $\mathrm{ft}^{3}$ for the connected tanks. This accounts for the various tank designs and the depth of waste in each tank.) If multiple tanks in a cascade are scheduled to be sampled, the total vapor space of the cascade is counted for each tank being sampled. This allows for the volatilization of toxics while no tanks in a cascade are being sampled. It is unlikely that the entire contents of a cascaded vapor space will be evacuated. It is also unlikely that during sampling of other tanks the vapor space concentration of toxics will reach the level existent before sampling. However, this assumption provides a conservative estimate of annual emissions.

Both Class $A$ toxic air pollutants (TAP), with an annual average ASIL, and Class B TAPs, with a 24-h average ASIL, are included in the design basis estimate of the vapor space.

To calculate the annual emissions of the Class A TAPs, the design basis concentration was multiplied by the quantity of vapor space to be exhausted and an annual average emission was determined. This information is included in Table 2, Emissions Estimate.

Also included in Table 2 is the hourly emission rate of $\mathrm{Cl}$ ass $\mathrm{B}$ TAPs, while the exhauster is operating at its rated flow of $5.7 \mathrm{~m}^{3} / \mathrm{min}^{3}\left(200 \mathrm{ft}^{3} / \mathrm{min}\right)$ (actual operation will be $\pm 1.4 \mathrm{~m}^{3} / \mathrm{min}\left( \pm 50 \mathrm{ft}^{3} / \mathrm{min}\right)$. The appropriate small quantity emission rate for each TAP is also included in the table, for comparison. 
Table 2. Emissions Estimate.

\begin{tabular}{|l|c|c|c|c|c|c|}
\hline \multirow{2}{*}{ Contaminant } & \multicolumn{2}{c|}{$\begin{array}{c}\text { Design } \\
\text { basis }\end{array}$} & \multicolumn{2}{c|}{$\begin{array}{c}\text { Maximum } \\
\text { anticipated }\end{array}$} & \multicolumn{2}{c|}{$\begin{array}{c}\text { Smal1 } \\
\text { quantity } \\
\text { emissions } \\
\text { rate }\end{array}$} \\
\cline { 2 - 8 } & $\begin{array}{c}1 \mathrm{~b} / \mathrm{h} \text { at } \\
200 \mathrm{ft}^{3} / \mathrm{min}\end{array}$ & $1 \mathrm{~b} / \mathrm{yr}$ & $\begin{array}{c}1 \mathrm{~b} / \mathrm{h} \text { at } \\
200 \mathrm{ft}^{3} / \mathrm{min}\end{array}$ & $1 \mathrm{~b} / \mathrm{yr}$ & $1 \mathrm{~b} / \mathrm{h}$ & $1 \mathrm{~b} / \mathrm{yr}$ \\
\hline \hline Acetone & 0.089 & & 0.28 & & 5 & \\
\hline Butanol & 0.23 & & 0.91 & & 5 & \\
\hline Benzene & & 1.36 & & 6.78 & & 20 \\
\hline (Hexane)/Octane & 0.0070 & & 0.035 & & 5 & \\
\hline Methyl Amine & 0.0095 & & 0.076 & & 0.6 & \\
\hline $\begin{array}{l}\text { Carbon } \\
\text { Tetrachloride }\end{array}$ & & 1.34 & & 6.66 & & 10 \\
\hline Ammonia & 0.10 & & 0.37 & & 0.6 & \\
\hline Hydrogen Cyanide & 0.00083 & & 0.091 & & 0.6 & \\
\hline $\begin{array}{l}\text { Nitric } \\
\text { Acid/(Oxides) }\end{array}$ & 0.019 & & 0.097 & & 0.2 & \\
\hline Carbon Disulfide & 0.0023 & & 0.012 & & 1.2 & \\
\hline Hydrogen Sulfide & 0.0010 & & 0.0052 & & 0.6 & \\
\hline
\end{tabular}

\subsection{COMPLIANCE WITH REQUIREMENTS}

Appendix B of this application includes a T-BACT assessment, which recommends no controls for organic or inorganic vapors.

The emissions resulting from the operation of the rotary mode coresampling truck are in compliance with the ASIL concentrations. This has been demonstrated by meeting the small quantity emission rates, as shown in Table 2.

Monitors for both TOC and ammonia will be operated continuously while the exhauster is operating. 


\subsection{REFERENCES}

Ecology, EPA, and DOE, 1990, Hanford Federal Facility Agreement and Consent Order, 2 vols., as amended, State of Washington Department of Ecology, U.S. Environmental Protection Agency, and U.S. Department of Energy, Richland, Washington.

PNL, 1992, Hanford Site Environmental Report for Calendar Year 1991, PNL 8148, Pacific Northwest Laboratory, Richland, Washington.

WAC 173-460, 1989, "Controls for New Sources of Toxic Air Pollutants," as amended.

WHC, 1991, Unit Dose Calculation Methods and Summary of Facility Effluent Monitoring Plan Determinations, WHC-EP-0498, Westinghouse Hanford Company, Richland, Washington.

WHC, 1993, Characterization of Vapors in Single Shell Tanks Scheduled for Rotary Mode Core Sampling, WHC-SD-WM-TI-536, Rev 0, Westinghouse Hanford Company, Richland, Washington. 
DOE/RL 93-41

This page intentionally left blank. 
DOE/RL 93-41

APPENDIX A

PRELIMINARY TANK ORDER

$A-1$ 
DOE/RL 93-41

This page intentionally left blank. 


\title{
APPENDIX A
}

\section{PRELIMINARY TANK ORDER}

\begin{abstract}
A preliminary list of the first 30 tanks to be sampled using the rotary mode core-sampling system is provided below. It should be noted that this list is subject to revision based on changing priorities at the Hanford Site.
\end{abstract}

- Tank 241-BY-104

- Tank 241-BY-110

- Tank 241-BY-107

- Tank 241-BY-105

- Tank 241-BY-103

- Tank 241-BY-112

- Tank 241-U-106

- Tank 241-TY-103

- Tank 241-BY-106

- Tank 241-BY-101

- Tank 241-TY-101

- Tank 241-U-107

- Tank 241-S-110

- Tank 241-TX-105

- Tank 241-SX-103
- Tank 241-SX-101

- Tank 241-BX-110

- Tank 241-SX-105

- Tank 241-AW-106

- Tank 241-SX-106

- Tank 241-S-112

- Tank 241-BX-111

- Tank 241-SX-104

- Tank 241-BY-111

- Tank 241-U-102

- Tank 241-A-101

- Tank 241-TX-118

- Tank 241-SX-102

- Tank 241-BY-108

- Tank 241-AX-101

The $A, A W, A X, B X$, and BY Tank Farms are located in the 200 East Area while the S, SX, TX, TY, and U Tank Farms are located in the 200 West Area. 
DOE/RL 93-41

This page intentionally left blank.

Aิ-4 
DOE/RL 93-41

APPENDIX B

BEST AVAILABLE CONTROL TECHNOLOGY FOR TOXICS ASSESSMENT 
DOE/RL $93-41$

This page intentionally left blank. 


\section{APPENDIX B \\ BEST AVAILABLE CONTROL TECHNOLOGY FOR TOXICS ASSESSMENT}

\section{B1.0 INTRODUCTION}

This document provides the basis for the management of toxic air pollutants resulting from rotary mode core-sampling activities. The information is intended to demonstrate that the control equipment selected for the exhauster for the rotary mode core-sampling system complies with the requirements concerning the Best Available Control Technology for Toxics (TBACT) as defined in the Washington Administrative Code (WAC) Chapter 173-460.1 The conclusions reached in this document are based on an evaluation of control technologies following the procedure described by the U.S. Environmental Protection Agency (in their draft policy document) ${ }^{2}$ and the State of Washington Department of Ecology in an implementation resource manual.

A description of the rotary mode core-sampling system, including the purpose for the system, is included in the Notice of Construction (NOC), to which this document has been appended. Please refer to the NOC for any information not directly related to the control of toxics.

\section{B2.0 UNABATED EMISSIONS}

The exact vapor space contents of the tanks to be sampled using the rotary mode core-sampling system are not known. However, based on process knowledge, limited vapor space analysis, and previous core samples of other tanks, a design basis concentration for several toxic air pollutants (TAP) was developed. This design basis represents a good engineering estimate of the content of the vapor spaces to be exhausted with the proposed system. Additionally, a maximum anticipated concentration was al so developed. Table B.1, Vapor Space Contents, shows the design basis concentration, and the maximum anticipated concentration, as well as the acceptable source impact level (ASIL) of each design basis contaminant subject to regulation by WAC $173-460$.

"WAC 173-460, "Controls for Non Sources of Toxic Air Pollutants," as amended, Washington Administrative Code, 1989.

${ }^{2}$ Prevention of Significant Deterioration and Nonattainment Area Permitting (Draft), U.S. Environmental Protection Agency, Washington, D.C., 1990.

${ }^{3}$ Regulating Toxics, Implementation Resource Manual, State of Washington Department of Ecology, Olympia, Washington, 1991. 
Table B.1. Vapor Space Concentration.

\begin{tabular}{|l|c|c||c|}
\hline \multirow{2}{*}{ Contaminant } & $\begin{array}{c}\text { Design basis } \\
\text { concentration }\end{array}$ & $\begin{array}{c}\text { Maximum } \\
\text { concentration }\end{array}$ & $\begin{array}{c}\text { TAP } \\
\text { class }\end{array}$ \\
\cline { 2 - 4 } & $\mathrm{p} / \mathrm{M}$ & $\mathrm{P} / \mathrm{M}$ & \\
\hline \hline Asetone & 50 & 160 & $\mathrm{~B}$ \\
\hline Butanol & 100 & 400 & $\mathrm{~B}$ \\
\hline Benzene & 2 & 10 & $\mathrm{~A}$ \\
\hline (Hexane)/Octane & 2 & 10 & $\mathrm{~B}$ \\
\hline Methyl Amine & 10 & 80 & $\mathrm{~B}$ \\
\hline Carbon Tetrachloride & 1 & 5 & $\mathrm{~A}$ \\
\hline Ammonia & 200 & 700 & $\mathrm{~B}$ \\
\hline Hydrogen Cyanide & 1 & 110 & $\mathrm{~B}$ \\
\hline Nitric Acid/(Oxides) & 10 & 50 & $\mathrm{~B}$ \\
\hline Carbon Disulfide & 1 & 5 & $\mathrm{~B}$ \\
\hline Hydrogen Sulfide & 1 & 5 & $\mathrm{~B}$ \\
\hline
\end{tabular}

*The two poliutants were grouped together in determining the concentration. It is assumed that all of the group could be attributed to the pollutant with the lower ASIL. The pollutant with the higher ASIL is in parenthesis.

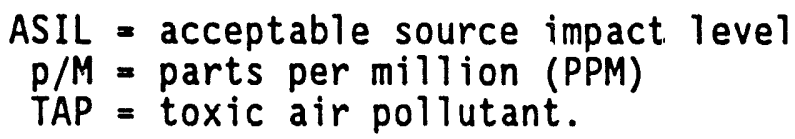

Most single-shell tanks (SST) have not had active ventil-tion on the vapor space for at least 10 years; all SSTs were declared in i. tive by 1980 . During that time, the volatile components of the waste have been allowed to come into equilibrium with the vapor space. It is anticipated that during the relatively brief time of exhausting each tank, little, if any, contaminants will volatilize from the waste. Using this assumption, the current vapor space is the only source term. The size of the vapor space can be calculated based on the depth of waste, the capacity of the tank, and the diameter of the tank. Unfortunately, the vapor space of the tank being sampled is not the only vapor space potentially exposed to the exhauster.

Many SSTs are connected to one or two other tanks by underground overflow lines, that were used when waste was cascaded from tank to tank, in an effort to separate the solids (and much of the radioactivity) from the supernate. These lines are above the level of waste in the tanks. It is not known what percentage of these overflow lines are blocked, or the extent of blockage in 
each line but the tanks cannot be isolated from other tanks in the cascade with any certainty. Consequently, when calculating the vapor space available for the exhauster, the vapor space of the other tanks in the cascade must be accounted for.

The calculation of total available vapor space was performed on the tanks to be rotary mode core-sampled (15 tanks per year, a very aggressive schedule) in the first $2 \mathrm{yr}$ and it was determined that approximately $193,000 \mathrm{~m}^{3}$ (6.8 million $\mathrm{ft}^{3}$ ) of vapor space is available to the exhauster. This includes the vapor space of the tanks connected to the tanks being sampled.

(2.3 million $\mathrm{ft}^{3}$ for the tanks being sampled, plus 4.5 million $\mathrm{ft}^{3}$ for the connected tanks. This accounts for the various tank designs and the depth of waste in each tank.) If multiple tanks in a cascade are scheduled to be sampled, the total vapor space of the cascade is counted for each tank being sampled. This allows for the volatilization of toxics while no tanks in a cascade are being sampled. It is unlikely that the entire contents of a cascaded vapor space will be evacuated. It is also unlikely that during sampling of other tanks the vapor space concentration of toxics will reach the levei existent before sampling. However, this assumption provides a conservative estimate of annual emissions.

Both Class A TAPs, with an annual average ASIL, and Class B TAPs, with a 24- $h$ average ASIL, are included in the design basis estimate of the vapor space.

To calculate the annual emissions of the Class A TAPs, the design basis concentration was multiplied by the quantity of vapor space to be exhausted and an annual average emission was determined. This information is included in Table B.2, Unabated Emissions.

Also included in Table B.2 $i$ : the hourly emission rate of Class $B$ TAPs, while the exhauster is operating at its rated flow of $5.7 \mathrm{~m}^{3} / \mathrm{min}\left(200 \mathrm{ft}^{3} / \mathrm{min}^{3}\right)$ (actual operation will be $\left.\pm 1.4 \mathrm{~m}^{3} / \mathrm{min}\left[ \pm 50 \mathrm{ft}^{3} / \mathrm{min}\right]\right)$. The appropriate small quantity emission rate for each TAP is also included in the table, for comparison. 
Table B.2. Unabated Emissions.

\begin{tabular}{|l|c|c|c|c|}
\hline \multirow{2}{*}{ Contaminate } & \multicolumn{2}{|c|}{ Design basis } & \multicolumn{2}{c|}{$\begin{array}{c}\text { Small quantity } \\
\text { emissions rate }\end{array}$} \\
\cline { 2 - 5 } & $1 \mathrm{~b} / \mathrm{yr}$ & $\begin{array}{c}1 \mathrm{~b} / \mathrm{h} \text { at } \\
200 \mathrm{ft} / \mathrm{min}\end{array}$ & $1 \mathrm{~b} / \mathrm{h}$ & $1 \mathrm{~b} / \mathrm{yr}$ \\
\hline Acetone & & 0.089 & 5 & \\
\hline Butanol & & 0.23 & 5 & \\
\hline Benzene & 1.36 & & & 20 \\
\hline (Hexane)/Octane & & 0.0070 & 5 & \\
\hline Methyl Amine & & 0.0095 & 0.6 & \\
\hline Carbon Tetrachloride & 1.34 & & & 10 \\
\hline Ammonia & & 0.10 & 0.6 & \\
\hline Hydrogen Cyanide & & 0.00083 & 0.6 & \\
\hline Nitric Acid/(0xides) & & 0.019 & 0.2 & \\
\hline Carbon Disulfide & & 0.0023 & 1.2 & \\
\hline Hydrogen Sulfide & & 0.0010 & 0.6 & \\
\hline
\end{tabular}

\section{B3.0 TOP DOWN PROCEDURE}

There are five basic steps to determine T-BACT for a source. The first step is to identify all available control options. The second step is to eliminate options that are technically not feasible. The third step is to rank the remaining control technologies in order of control effectiveness. The fourth step is to evaluate the most effective controls considering energy, environmental, and economic impacts. If the top candidate is shown to be technically or economically not feasible, the next most stringent alternative is evaluated. Finally, a T-BACT selection is made when the most effective control option cannot be eliminated because of energy, environmental, or economic impacts.

\section{B4.0 CONTROL TECHNOLOGIES AVAILABLE}

Several technologies are available for the control of the contaminants included in the unabated emissions estimate. It should be noted that the exhauster will be equipped with a HEPA filter, regardless of the recommendation of this T-BACT analysis as a result of the requirements of WAC 246-247 and the U.S. Department of Energy. 
Both organic and inorganic compounds are included in the unabated emissions estimate. The control technologies for each type of compound will be discussed separately.

\section{B4.1 CONTROLS FOR VOLATILE ORGANIC COMPOUNDS}

This section describes the various technologies for the control of volatile organic compounds. The technical feasibility of each is discussed in this section, as well.

\section{B4.1.1 Adsorption}

This technology has been used widely to capture volatile organic compounds (VOC) from emission sources. The stream is passed through a fixed bed of granular activated carbon, and adsorbed onto the carbon, or another adsorbent, such as a resin. This eventually depletes the available sites for adsorption, and the adsorbent must be either regenerated or discarded. This option appears to be technically feasible and will be discussed further in Section 5.1.

\section{B4.1.2 Thermal Incineration}

In this technology, the air stream is heated to about 816 to $1093{ }^{\circ} \mathrm{C}$ ( 1500 to $2000^{\circ} \mathrm{F}$ ) for about a 1 second residence time. This chemically oxidizes the VOCS. Due to the relatively low heat content of the air stream, and the variability from tank to tank in vapor space composition, large quantities of fuel would be required for incineration, adding another large component (the fuel tank) to the rotary mode core-sampling system. Because of the potential presence of hydrogen in the vapor space of some of the tanks to be rotary mode core-sampled this technology would not be considered inherently safe. Additionally, any system which would remove the incineration source from the proximity of the tank to minimize safety concerns would not be feasible, because the exhaust system cannot be outside of the fenceline of the tank farm being exhausted. Consequently, installation is not technically feasible on any Hanford Site waste storage tank.

\section{B4.1.3 Catalytic Incineration}

Catalytic Incineration operates in the same manner as thermal incineration, with the exception that a catalyst is used in the reaction bed to reduce the temperature required to oxidize the VOCs. The presence of chlorinated compounds in the air stream will degrade the capability of the catalyst. Additionally, the temperatures required for this control technology are not sufficiently low that the inherent safety of the system can be ascertained. Therefore, catalytic incineration is not technically feasible for this application. 


\section{B4.1.4 Vapor Condensation}

This technology is used to recover and recycle volatilized solvents from industrial processes and in some cases has been used for VOC emission control, if the VOC concentration is extremely high. The air stream to be treated is cooled to below the dewpoint temperature of the VOC to be collected, and the condensed VOCs are decanted and recovered. This technology is not applicable to air streams with widely varying composition or concentration, because of the difficulties in designing the condenser for an uncertain process stream. Also, this technology is not well suited to air streams where the VOC concentration is less than the water vapor concentration, because the air coolers will become clogged with condensed ice. The tanks to be exhausted with this system are of highly varying composition, and some of the tanks are expected to have extremely high relative humidities. Therefore, this technology is not technically feasible.

\section{B4.2 CONTROLS FOR INORGANIC COMPOUNDS}

Only a limited quantity of methods have developed to control inorganic vapor emissions from point sources. The two most commonly used control methods are adsorption and absorption (or scrubbing).

\section{B4.2.1 Adsorption}

Adsorption of inorganic compounds is performed in the same way the adsorption of organic compounds is performed on granular activated carbon, however the adsorbent is different. For the control of ammonia (by far the inorganic compound of highest concentration in the design basis vapor space), impregnated carbon has been shown to be an effective control devise. This option appears to be technically feasible and will be discussed further in Section B5.2.

\section{B4.2.2 Absorption}

Absorption, or scrubbing, is used quite extensively in the control of inorganic compounds. In this technology, the air stream is contacted with a solvent, in which the inorganic compounds are highly soluble. The ideal solvent should be nonvolatile, noncorrosive, nonflammable, nontoxic, chemically stable, readily available, and inexpensive. Water is the most commonly used solvent, and is used on a once-through basis. Unfortunately, there is no wastewater disposal system in the tank farms that can handle the quantity of wastewater that will be generated by this process. Additionally, there is a restriction on the water brought into the SST farms. This does not allow for water to be brought in to scrub the air stream and removed from the fan for treatment el sewhere onsite. Therefore, this technology is not technically feasible. 


\section{B4.2.3 Incineration}

Thermal or catalytic incinerators can be used to control the emission of some inorganic compounds, including most of those included in the design basis emission estimate. However, the same technically infeasibility exists when applying these high temperature devises on tanks potentially containing concentrations of hydrogen in excess of the lower explosive level.

\section{B5.0 RANKING OF CONTROL TECHNOLOGIES}

Adsorption is the only technically feasible control technology available for organic or inorganic compounds. Therefore adsorption is ranked first, in order of effectiveness, and "no controls" is ranked second.

\section{B6.0 ENVIRONMENTAL, ECONOMIC, AND ENERGY IMPACTS}

The rotary mode core-sampling system has been developed with the primary goal of sampling the waste in the SSTs as efficiently, rapidly, and thoroughly as possible, while maintaining the integrity of the samples. Determining the contents of the tanks is the first step in retrieval, treatment, and eventual disposal of the wastes, which is required for the clean-up of the Hanford Site.

At the flow rate selected for this exhauster, the technical feasibility of adsorption systems is questionable. EPA handbook $625 / 6-91 / 014^{4}$ does not recommend adsorption for flows less than $8.5 \mathrm{~m}^{3} / \mathrm{min}\left(300 \mathrm{ft}^{3} / \mathrm{min}\right)$ or temperatures greater than $54.4{ }^{\circ} \mathrm{C}\left(130^{\circ} \mathrm{F}\right)$. To install these controls the flow rate would have to be increased and a chiller installed to ensure that the air stream was within the design parameters of the adsorption systems. Additionally, the pressure drop through the control technologies would cause the pressure in the tank to fall below acceptable safety criteria $(<-7.62 \mathrm{~cm} \mathrm{w.g.} \mathrm{[<-3} \mathrm{in.} \mathrm{w.g.]).} \mathrm{Addition} \mathrm{of} \mathrm{a} \mathrm{chiller} \mathrm{and} \mathrm{use} \mathrm{of} \mathrm{a} \mathrm{higher}$ flow rate are technically feasible and are required for adsorption to be feasible. Consequently, the following discussion of impacts includes the use of a higher flow rate and chiller system.

\section{B6.1 ENVIRONMENTAL IMPACTS}

A system designed with the adsorption units would be extremely large, and would place the sampling of SSTs on a much slower track. Actual rotary mode core-sampling can take up to 21 days per tank. With the exhauster using VOC and ammonia adsorption, set-up and break-down would take as long. Therefore,

${ }^{4}$ Control Technologies for Hazardous Air Pollutants, EPA/625/6-91/014, U.S. Environmental Protection Agency, Washington, D. C., 1991. 
less than 9 tanks could have been sampled in a year. The Tri-Party Agreement ${ }^{5}$ requires cores from 24 tanks in fiscal year 1995, 1996, and 1997. At a rate of 9 rotary mode tanks per year, this is not possible. Delaying the sampling of SSTs provides an environmental impact to the clean-up of the Hanford Site.

An adsorption system for the VOC was identified. This system used inplace regeneration with nitrogen and therefore did not have a significant secondary waste generation problems. However, there is an environmental impact in the generation of spent impregnated carbon from the ammonia adsorption systein.

\section{B6.2 ECONOMIC IMPACTS}

Operating costs for obtaining a single core from a SST are an additional $\$ 185,000$ for the exhauster with the adsorption systems in place. At a sampling rate of 30 cores per year (i.e., 15 tanks per year, 2 cores per tank), $\$ 5,550,000 / y r$, would be spent on the operation of the two systems (this does not include a percentage of the capital costs of the two systems). At 99 percent efficiency, the two systems could remove up to $34.3 \mathrm{~kg}(75.6 \mathrm{lb})$ of TAPs per year (if all tank vapor spaces are at design basis concentrations). Therefore, the operating cost of the adsorption systems is $\$ 147$ million/ton of TAPS $(\$ 73,400 / 16$ of TAPS $)$.

\section{B6.3 ENERGY IMPACTS}

The operation of the previously designed system (including the VOC adsorber regeneration) required approximately $175 \mathrm{kVa}$ additional power. The power to the rotary mode core-sampling system is supplied by a diesel generator, and the additional power requirements would require more than 200 additional horsepower to be supplied by the generator.

Using AP-42 (Section 3.3) factors for diesel engines, at $200 \mathrm{hp}$, operating $10 \mathrm{~h} / \mathrm{d}, 21$ days per tank, and 9 tanks/yr, almost 9 tons of criteria pollutants are emitted from the generator per year. (Additional power is not available in tank farms.) Therefore, to remove less than $34.5 \mathrm{~kg}$ (76 1b) of toxics from the air stream, 9 tons of criteria pollutants would be discharged to the atmosphere.

${ }^{5}$ Hanford Federal Facility Agreement and Consent Order, 2 vols., as amended, State of Washington Department of Ecology, U.S. Environmental Protection Agency, and U.S. Department of Energy, Richland, Washington, 1990. 


\section{B7.0 TECHNOLOGY SELECTION}

The unabated emissions as a result of the planned activity do not represent significant emissions to the atmosphere. (If the emissions were significant, the small quantity emission rates would be exceeded and dispersion modeling would be required.) Additionally, the impacts of the control technology are not justified in the removal of an insignificant quantity of pollutants. 
DOE/RL 93-41

This page intentionally left blank.

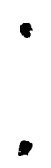


DOE/RL 93-41

\section{DISTRIBUTION}

Number of copies

OFFSITE

1

Benton-Frankl in-Walla Walla Counties

Air Pollution Control Authority

Richland, WA 99352

Dr. D. A. Lauer

3

State of Washington Department of Ecology

S. Brush

J. Drabek

R. C. H. King

PV-11

PV-11

PV -11

ONSITE

5

U.S. Department of EnerqyRichland Operations Office

J. M. Clark

$P$. R. Hernandez

A4-02

E. M. Mattl in

S. D. Stites

A4-02

Public Reading Room

A4-02

A5- 15

A $1-65$

1

Pacific Northwest Laboratory

Technical Library

$\mathrm{K} 1-11$

21

West inghouse Hanford Company

B. A. Austin

B2-35

J. A. Bates

H6-22

F. 0. Grey

A2-24

D. B. Hagmann

S2-46

G. W. Jackson

H6-21

J. R. Kasper

R2-50

R. J. Landon

J. J. Luke

H6-22

P. J. Mackey

H6-25

M. J. Minette

B3-15

R. W. Oldham

S2-46

D. N. Price

H6-25

J. D. Robinson

R2-14

C. E. Sowa (3)

H5-09

W. F. Zuroff

H6-25

CES File/LB 
DOE/RL 93-41

\section{DISTRIBUTION (cont)}

Document Processing and Control

L8-13

EDMC

H6-08

Information Release Administration

A3-36

- 
